DOI https://doi.org/10.30525/978-9934-26-180-0-5

\title{
ЛЕКСИКО-АСОЦІАТИВНЕ ПОЛЕ СИМВОЛУ ВОДА У СВІТОГЛЯДНИХ УЯВЛЕННЯХ УКРАЇНЦІВ
}

\author{
Швидка Н. В. \\ кандидат філологічних наук, доцент, \\ доиент кафедри украӥнської мови та літератури \\ Донбаський державний педагогічний університет \\ Швидкий С. М. \\ доктор історичних наук, дочент, \\ дочент кафедри украӥнської мови та літератури, \\ проректор з науково-педагогічної роботи \\ Донбаський державний педагогічний університет \\ м. Слов'янськ, Донеиька область, Україна
}

Символьне світосприймання марковане системою мовних одиниць $\mathrm{i}$ способами моделювання світу, що $є$ передумовою формування мовного архетипу. Лише архетипні символи зберігають однакове значення в ритуалах, обрядах, фольклорі, релігії, мистецтві тощо. Символи-архетипи формувалися на тому етапі мислення, коли людина оперувала магічною образністю й символікою. Архетип, міфологема, символ є історично сформованою сукупністю взаємопов'язаних мотивів, образів, значень, які здатні розгорнутися в сюжет й об'єктивувати зміст. Як зазначав Ю. Лотман, окремий символ - це ізольований текст, який вільно функціонує у хронологічній площині культури й корелює 3 iï синхронними сферами [5, с 146].

У межах тексту архетипи зі структур свідомості трансформуються в образи-знаки, кваліфікація яких залежить від сформованого ним контекстуального змісту. Серед значень образно-ідейної сукупності символ виокремлює його позачасову ідею на відміну від архетипу, який конденсує історичну пам'ять нації. Архетипні символи мають однакове чи схоже значення для значної частини людства. Таким архетипом є і вода як елемент першобуття, йому притаманні різні поняття: вода символізує життя, здоров'я, очищення, зцілення, відновлення, пророкування, символічно маркує смерть, $є$ джерелом хаосу й небезпеки тощо.

Вода у світоглядних уявленнях українців - це життєдайна підвалина світотворення, іiі вважають Праматір'ю Світу. В українській народній творчості вода $є$ межею між світами й станами людського буття, водночас 
символізує силу та енергію дівчини й жінки, їхню красу й жіночі чари. Як зазначав О. Потебня, вода формує асоціативну парадигму в пісенній творчості: дівоча краса, про красивих, здорових дівчат кажуть: Гожа, як чиста вода; Така гарна, хоч з лиия води напитися (з лиия воду пий); Здорова, як вода; Глянь у воду на свою вроду; вода чиста - дівка мила, вода нечиста - дівка невірна; вода каламутна - дівка баламутна; хотіти пити жадати кохання; напитися води - задовольнити любовну спрагу; давати пити іншому - зраджувати чоловікові; воду розливати - символ розлуки тощо [6, с. 457].

Асоціативна образність символу вода притаманна багатьом ритуалам сімейної обрядовості, зокрема вода у весільній обрядовості символізує межу, яку перетинають молоді, змінюючи свій соціальний статус. Для нареченої як лімінальної істоти перехід до нового роду рівнозначний ініціальному поняттю смерті, де вода уособлює шлях в «інший світ», що символізує поєднання двох родів, які живуть ніби на різних берегах річки. Умовну річку-рубіж утворювали переливанням дороги, якою йшли молоді. Магічна функція води полягає в очищенні від усього лихого, що було в попередньому житті. 3 таким знаком-символом щастя молоді вступають у подружнє життя. Обряд умивання молодих полягав у тому, що їх вели до річки (криниці). У давні часи шлюби брали біля водойм, це символізувало парування, запліднення, розмноження. Оберегова функція води вербалізована словосполученням обливання водою - магічний обряд насилання щастя-долі молодим. Водою скроплювали й наречених, i весільні атрибути, насамперед їхні барвінкові вінки.

В обряді пологів проливання води символізує розкриття джерел. У родильній обрядовості визначальним для подальшої долі немовляти була його перша купіль: баба з води обливає, зливає водою й ім'я дає. Повитуха під час купання могла вдосконалити фізичні якості дитини, здійснити перше пророкування майбутньої долі народженого. Нагріваючи воду, пильнували, аби вона не закипіла, щоб дитина не стала запальною, злою та сердитою. В українців відомим $є$ прислів'я У гарячій воді купаний [1, с. 151]. Традиційним було купання немовляти в нечистій воді (щоб голий не був купель), на відміну від чистої води (без будь-яких добавок), якою обмивали покійного. У першу купіль передусім додавали зілля, кидали гроші (щоб дитина була багата), лили свячену воду, сипали пшоно (щоб не нападала жовтуха), кидали березову тріску (бо береза родюча), для дівчаток кидали коралі й додавали невелику кількість молока (щоб була красивою й хлопиі любили) [1, с. 157].

Усталені конструкції мертва вода, чиста вода, вода для душі притаманні поховальній обрядовості. У селах ще пам'ятають звичай 
обмивання покійного. Вірили, тому, хто допомагає обмивати небіжчика, його рядити, гріхи прощаються. Таку воду називають мертвою, локусом iii утилізації обирають місце, де ніхто не ходить, або таке місце, яке під час дощу змивалося б водою. Атрибутом прощання з небіжчиком є вода для душі, яку зазвичай виставляють на вікні. Вербальна формула мотивації наявності такого атрибута є традиційною: душа виходить, треба їй води напитися. Особливий статус води для душі зумовлений високим рівнем небезпеки: як перекиниться вода - хутко покійник буде [2, с. 34]. Отже, вода $€$ постійним супутником людини від народження аж до смерті.

Атрибутне обрамлення модифікує архетипний символ вода як маркер зцілення, оберегу, плодючості. Воду, що залишили на ніч під зоряним небом, українці називають зоряною. За повір'ям, така вода набувала лікувальних й оберегових властивостей, зокрема ії давали коровам для збільшення кількості молока. Йорданська воду - річкову, набрану на свято Водохреща, вважали особливо цілющою, бо в ній хрестили Iсуса. Цей ритуал ще називають Водосвяття (велике освячення води на Святе Богоявлення), а воду - богоявленська. Набрана в цей день 3 річки, вона здатна вилікувати найтяжчу хворобу, нею окроплювали все обійстя, аби захистити від нечистої сили. Живу воду - джерельну, набрану з трьох чи семи криниць, пили, окроплювалися нею, купалися в ній, щоб набути великої сили. «Юріївкою», «Юр’євою росою» (за церковним календарем, 23 квітня /6 травня відбувався масовий вигін худоби) пастуха й худобу обливали водою, у яку додавали росу, що сприяло іiі плідності й молочності, а обом додавало здоров'я. Обряд першого вигону худоби пояснюють народні перекази: «Святий Юрій відмикає весною небо й пускає росу на землю» [3, с. 108].

На окрему увагу заслуговують обрядодії, пов'язані з очищувальною властивістю води; такі обряди в лікувальній магії пояснювали тим, що вона, згідно із законом імітативної магії, так само могла очистити людину від хвороби, i, за аналогією, у ній вбачали зцілення майже від усіх недуг. На думку М. Еліаде, «...як у космологічному, так і в антропологічному планах занурення у воду не означає остаточного згасання, це тимчасове повернення в невиразне, за яким іде нове творення, нове життя чи «нова людина» [4, с. 69]. Особливого значення надавали проточній воді (вона забирає хворобу разом з кинутими в неї предметами) $\mathrm{i}$ «непочатій воді». Другу набирала знахарка, яка вдягалася як на свято, і вночі йшла в супроводі кого-небудь брати воду 3 трьох криниць. Перед кожною криницею робила три земних поклони й говорила: «Господи Icyce Христе, Сине Божий, помилуй нас, амінь. Здоров, земля Тетяно, а вода Оляна! Благослови мене, Господи, водииі набрати рабу Божому (ім'я)» [7, с. 181]. Надзвичайно ефективною вважали воду чи росу, зібрану на великі 
релігійні свята. У кожній родині зберігали освячену стрітенську, великодню, благовіщенську воду.

На особливу увагу заслуговують ритуальні дії з водою в купальській обрядовості. За віруваннями, спільними для всіх слов'ян та інших європейських етносів, вода в Іванівську ніч набуває особливо цілющих властивостей. У багатьох місцевостях України хворим, особливо на шкірні хвороби, радили в цей день до схід сонця скупатися в річці. Від вроків напували, умивали й змочували різною водою: свяченою, наговореною, непочатою й отриманою від обмивання особливо шанованою іконою [7, с. 180].

Водночас воду сприймали як джерело хаосу й небезпеки. В Україні побутували давні вірування в те, що в різних водоймах живе нечиста сила, душі потопельників. Воду вважали місцем, з якого поширюються недуги, стихією чи речовиною, яка внаслідок певних обставин чи дій стає небезпечною. Такі уявлення зумовили чимало своєрідних світоглядних і звичаєвих явищ: віру в існування певних міфологічних персонажів, локалізованих у воді (потопельник, русалка, щезник, водяний упир, гадячий цар тощо); виникнення замовлянь 3 відсиланням хвороб і нечисті за моря, у воду, з водою; «насилання» чарів водою (біля ріки або тією, у якій обмивали небіжчика чи вимочували зміїну шкіру); настанов і заборон щодо зберігання та вживання води, купання у водоймах у певні періоди року і вночі.

Отже, образність, що формує лексико-асоціативне поле символу вода, набуває у світоглядних уявленнях українців особливого семантичного навантаження, маніфестує змістову багатогранність цього архетипу й насамперед має таке функційне навантаження: очищення (як фізичне, так і духовне), зцілення, насилання щастя-долі, парування, запліднення, пророкування майбутньої долі тощо. Зазначений символ моделює парадигму вербалізаторів, які охоплюють і периферійні відгалуження номінацій, співвіднесених з водою денотатів (річка, криниця, дощ, роса, Івана Купала, Чистий четвер, купання, обмивання, умивання, потопельник, щезник, русалка тощо). Символічні співвідношення образності води в обрядодіях репрезентовані різноманітними модифікаторами, зокрема зоряна вода, непочата вода, освячена вода, йорданська (богоявленська) вода, благовіщенська вода, великодня вода, «юріївка», жива вода, мертва вода, переливання дороги, обливання водою молодих, проливання води, перша купіль, вода для душі тощо. Аналіз сталих мовних сполук, які $\epsilon$ похідними обрядових контекстів, потребує не лише оперування певними мовними процесами, а й застосування відповідних знань 3 історії, культури, фольклору. Образність і символіка таких одиниць $є$ надбанням народної філософії, етики й естетики. 


\section{Література:}

1. Боряк Олена. Баба-повитуха в культурно-історичній традиції українців: між профанним і сакральним. Інститут мистецтвознавства, фольклористики та етнології ім. М. Т. Рильського НАН України. Київ, 2009. $279 \mathrm{c}$.

2. Гаврилюк Н. К. Київськополіський варіант традиційної сімейної обрядовості на фоні суміжних територій. Київське Полісся. Етнолінгвістичне дослідження / відп. ред. І. Железняк. Київ: Наукова думка, 1989. С. 24-40.

3. Жайворонок В. В. Знаки української етнокультури: словникдовідник. Київ: Видавництво «Довіра», 2006. 703 с.

4. Еліаде М. Мефістофель і андрогін / пер. $з$ французької Г. Кьорян. Київ: Основи, 2001. С. 305-467.

5. Лотман Ю. М. Внутри мыслящих миров. Человек-ТекстСемиосфера-История. Москва: Языки русской культуры, 1996. 464 с.

6. Потебня А. Объяснения малорусских и сродных народных песен. Колядки и щедровки. Варшава: Типографія М. Зишкевича, 1987. T. 29. 809 c.

7. Швидкий С. М. Етнокультурна спадщина населення Слобідської України XIX-початку XXI ст. у системі сучасних знань та світоглядних уявлень: монографія. Слов'янськ: Вид-во Б. І. Маторіна, 2016. 409 с. 